\title{
EFFECTS OF PROTEIN KINASE INHIBITORS 1(5-ISOQUINOLINESULFONYL)-2-METHYLPIPERAZINE DIHYDROCHLORIDE (H-7) AND $N$-[2-GUANIDINOETHYL]- 5-ISOQUINOLINESULFONAMIDE HYDROCHLORIDE (HA1004) ON CALCITRIOL-INDUCED DIFFERENTIATION OF HL-60 CELLS*
}

\author{
Robert E. MARTEll, Robert U. Simpson $\dagger$ and TODd Hsu \\ Department of Pharmacology and The Center for Molecular Genetics, University of Michigan, \\ School of Medicine, Ann Arbor, MI 48109, U.S.A.
}

(Received 8 May 1987; accepted 8 July 1987)

\begin{abstract}
HL-60 promyelocytic leukemia cells were induced to differentiate by 1,25 -dihydroxyvitamin $\mathrm{D}_{3}$ (calcitriol) into mature monocytes. Differentiation was assessed by nitro blue tetrazolium dye reduction, nonspecific esterase activity, and DNA synthesis. Terminal differentiation of cultures induced by calcitriol $(10 \mathrm{nM})$ was inhibited by $80 \%$ when cells were treated simultaneously with protein kinase inhibitors 1-(5-isoquinolinesulfonyl)-2-methylpiperazine dihydrochloride (H-7) $(32 \mu \mathrm{M})$ and $N$ - $[2$ guanidinoethyl]-5-isoquionlinesulfonamide hydrochloride (HA1004) $(320 \mu \mathrm{M})$. The $\mathrm{IC}_{50}$ for inhibition of calcitriol-induced differentiation was approximately $15 \mu \mathrm{M}$ for $\mathrm{H}-7$ and $170 \mu \mathrm{M}$ for HA1004. 'The IC 50 values for H-7 and HA1004 antagonism of calcitriol-induced differentiation are quantitatively and relatively correlated to their known action to inhibit protein kinase $\mathrm{C}$ activity. Treatment of cells with concentrations of $0-32 \mu \mathrm{M} \mathrm{H}-7$ or $0-320 \mu \mathrm{M}$ HA1004 alone did not affect cell growth, differentiation, or trypan blue exclusion. However, higher concentrations of $\mathrm{H} 7(>32 \mu \mathrm{M})$ and HA1004 $(>320 \mu \mathrm{M})$ were found to be cytotoxic. The data presented suggest that calcitriol-induced differentiation is antagonized by inhibitors of protein kinase and are consistent with the hypothesis that kinase $\mathrm{C}$ activity is required for HL-60 cell differentiation.
\end{abstract}

Human HL-60 promyelocytic leukemia cells constitute a useful cell culture system for the study of cellular differentiation. HL-60 cells can be induced to terminally differcntiate to morphologically mature myeloid cells by a wide variety of compounds including DMSO $\ddagger$, RA, phorbol diesters and calcitriol [19]. DMSO and RA induce mature neutrophil-like cells, whereas calcitriol and phorbol diesters induce differentiation to a monocyte-macrophage phenotype [1-9]

In this report we studied the relationship between differentiation induced by phorbol diesters and cal-

* This research was supported by NIH Grant CA 36507 , a grant from the Children's Leukemia Foundation of Michigan, and a grant from the Cancer Research Institute of the University of Michigan.

$\dagger$ Address reprint requests to: Robert U. Simpson, Ph.D., Department of Pharmacology, M6322 Medical Science Building I, University of Michigan, Ann Arbor, MI 48109-0626.

$\$$ Abbreviations: H-7, 1-(5-isoquinolinesulfonyl)-2methylpiperazine dihydrochloride; HA1004, $N$-[2-guanidinoethyl]-5-isoquinolinesulfonamide hydrochloride; DMSO, dimethyl sulfoxide; RA, retinoic acid; PKC, protein kinase $\mathrm{C}$; calcitriol, 1,25-dihydroxyvitamin $\mathrm{D}_{3}$; TPA, 12-O-tetradecanoylphorbol 13-acetate; NEA, nonspecific esterase activity; HEPES, $n$-2-hydroxyethylpiperazine- $N^{\prime}$ 2-ethanesulfonic acid; IQSA, isoquinolinesulfonamide; PBS, phosphate-buffered saline; NBT, nitro blue tetrazolium; and TCA, trichloroacetic acid. citriol. Biologically active phorbol diesters have been shown to interact with a calcium and phospholipiddependent protein kinase $[10-14]$. There is much evidence indicating that the receptor for phorbol diesters is protein kinase $\mathrm{C}$ (PKC) $[10-14]$. We recently demonstrated that phorbol diester receptor levels increase early in the course of calcitriolinduced differentiation [15]. Lane et al. [16] have shown that DMSO-induced differentiation is also accompanied by increased levels of phorbol diester receptor. These observations suggest that the phorbol diester receptor, $\mathrm{PKC}$, is involved in calcitriolinduced differentiation.

Inhibitors of protein kinase activity have been synthesized and characterized [17]. Isoquinolinesulfonamides (IQSA) interact directly with the catalytic site of the protein kinase and most likely induce their response by competing with ATP binding to kinases. Hidaka et al. [17] have characterized the relative potency of IQSA kinase inhibitors and have shown that 1-(5-isoquinolinesulfonyl)-2-methylpiperazine dihydrochloride $(\mathrm{H}-7)$ is more potent (10-fold) an inhibitor of PKC than $N$-(2-guanidinoethyl)-5-isoquinolinesulfonamide hydrochloride (HA1004). In contrast, these studies showed that HA1004 was a more potent inhibitor of cGMP. and cAMP-dependent protein kinases than PKC [17]. These IQSA inhibitors are readily incorporated into intact cells [17]. Furthermore, $\mathrm{H}-7$ has been used by others to study protein kinase $\mathrm{C}$ dependent 
processes in isolated intact platelets and in aortic and atrial muscle preparations [18-19]. In the present study, we examined the effects of inhibitors of protein kinases (H-7 and HA1004) on calcitriol-induced HL-60 cell differentiation.

\section{MATERIALS AND METHODS}

$\left[{ }^{3} \mathrm{H}\right]$ Thymidine was purchased from New England Nuclear (Boston, MA). Dulbecco's phosphate-buffered saline (PBS), bovine gamma globulin, horse serum, HEPES buffer, citrate buffer, Trizma 7.6 buffer, fast blue RR salt, alpha napthyl acetate, Mayer's hematoxylin Triton X-100 solution and TPA were all purchased from Sigma (St. Louis, MO). H-7 and HA1004 were purchased from Seikagaku America Inc. (St. Petersburg, FL). Calcitriol was purchased from the Du Phor Co. (Amsterdam, Netherlands). Vitamin D metabolite purity and structural integrity were confirmed by UV spectroscopy. HL-60 promyelocytic leukemia cells were obtained from Dr. Beverly Mitchell of The University of Michigan and cultured in RPMI 1640 medium from Irvine Scientific (Irvine, CA) with $10 \%$ horse serum in a humidified atmosphere of $95 \%$ air and $5 \% \mathrm{CO}_{2}$ at $37^{\circ}$

Differentiation of HL-60 cells. HL-60 cells in log phase growth at an initial cell count of approximately $2 \times 10^{5}$ cells $/ \mathrm{ml}$ were treated with ethanol or $10 \mathrm{nM}$ calcitriol and various concentrations of $\mathrm{H}-7$ or HA1004 (vehicle $50 \% \mathrm{ETOH}$ ) for periods as noted for each experiment. Cell differentiation was assessed by NBT dye reduction, nonspecific esterase activity, and DNA synthesis.

$N B T$ dye reduction. Assessment of cell differentiation in control and treated cells was measured by NBT reduction as previously described [18]. Cells at a density of $1 \times 10^{6}$ cells $/ \mathrm{ml}$ in growth medium containing $10 \%$ horse serum were incubated for $80 \mathrm{~min}$ at $37^{\circ}$ in an atmosphere of $5 \% \mathrm{CO}_{2}$ and air with an equal volume of NBT $(2 \mathrm{mg} / \mathrm{ml})$ solution which contained TPA at a final concentration of $500 \mathrm{nM}$. The percentage of cells containing intracellular blue-black formazan deposits was determined by microscope examination immediately after NBT incubation. Relative cell concentrations were obtained as well since cell solution counting was done with a hemacytometer. Triplicate determinations of at least 100 cells were performed for each treated culture.

Nonspecific esterase activity. Nonspecific esterase activity was determined cytochemically using a commercially available kit (Sigma Chemical $\mathrm{Co}$ ). After centrifugation and aspiration of the medium, cells were spread on a glass microscope slide, air dried, and fixed with a citrate-acetone-methanol fixative. The stain was prepared by mixing $200 \mu \mathrm{g} / \mathrm{ml}$ Fast Blue RR salt in Trizmal, $\mathrm{pH} 7.6$, buffer and a second solution containing $10 \mathrm{mg} / \mathrm{ml}$ of alpha naphthyl acetate in ethylene glycol monomethyl ether. These solutions were combined at $37^{\circ}$ in a $25: 1$ ratio, respectively, and added to staining jars. Slides were incubated for $30 \mathrm{~min}$ at $37^{\circ}$ in staining solution. Slides were then counterstained in Mayer's hematoxylin solution for $5 \mathrm{~min}$. The percentage of cells containing dark blue deposits was quantitated visually by micro- scope. A minimum of three slides with 100 cells each was counted.

Measurement of DNA synthesis. HL-60 cells were assayed for DNA synthetic capacity as previously described [15]. At indicated time points and various treatment regimens, cells were incubated in the presence of $1 \mu \mathrm{Ci}$ of [ ${ }^{3} \mathrm{H}$ thymidine (sp. act. $20 \mathrm{Ci} / \mathrm{mmol}$ ) per $\mathrm{ml}$ of growth medium for $1 \mathrm{hr}$. Cells were collected and rinsed twice in phosphate-buffered saline, lysed with $600 \mu \mathrm{l}$ of $1 \mathrm{~N} \mathrm{NaOH}$ at $37^{\circ}$ for $30 \mathrm{~min}$, and neutralized with $1 \mathrm{~N} \mathrm{HCl}$. Total protein was assayed by the method of Bradford [20] Acid-insoluble material was precipitated by addition of $2 \mathrm{ml}$ of icecold $10 \%$ TCA. TCA prepipitates were collected on $2.4 \mathrm{~cm}$ Whatman GF/C glass fiber filters, washed twice with ice-cold $10 \%$ TCA and once with ice-cold ethanol. Filters were dried and counted using liquid scintillation spectroscopy.

\section{RESULTS}

Inhibition of differentiation by markers $\mathrm{H}-7$ and $H A 1004$. The effects of protein kinase inhibitors $\mathrm{H}$ 7 and HA1004 on calcitriol-induced differentiation are shown in Figs. 1 and 2. Figure 1 shows the effects of $\mathrm{H}-7$ and HA1004 on calcitriol-induced NBT reduction capacity in HL-60 cells. Each point is represented as a percentage of markers expressed in cultures that were treated with calcitriol $(10 \mathrm{nM})$ and no kinase inhibitor. Standard error was determined by examining three microscope fields of at least 100 cells for each data point. The $\mathrm{IC}_{50}$ for inhibition of differentiation was approximately $11 \mu \mathrm{M}$ for $\mathrm{H}-7$ and $200 \mu \mathrm{M}$ for HA1004 for this experiment (Fig. 1). Similar results were obtained in three other separate experiments. Differentiation was further assessed using another marker for differentiation, nonspecific esterase activity. Figure 2 shows the concentration-

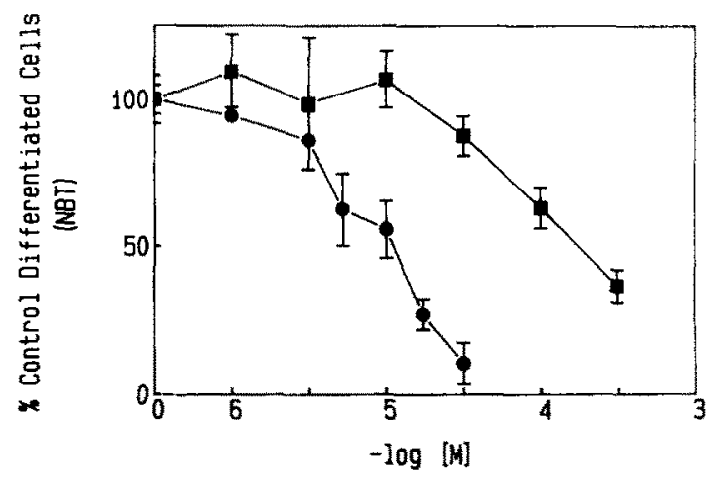

Fig. 1. Concentration-dependent effects of H-7 and HA1004 on a calcitriol $(10 \mathrm{nM})$ induced HL-60 differentiation marker, NBT dye reduction. Cultures of cells treated with calcitriol for $48 \mathrm{hr}$ and microscopically assayed for cell NBT dye reduction capacity were found to exhibit this differentiation marker in $58 \pm 3 \%(\mathrm{~N}=3 \pm \mathrm{SE})$ of cells. We assayed cellular NBT dye reduction capacity in cultures simultaneously treated with calcitriol $(10 \mathrm{nM})$ and various concentrations of $\mathrm{H}-7(\boldsymbol{)})$ and HA1004 (西). Data are expressed as percent of control cells exhibiting NBT reduction by $10 \mathrm{nM}$ calcitriol $(100 \%)$ in the absence of $\mathrm{H}-$ 7 or HA1004. Each point is the mean of three determinations $( \pm S E)$. Four identical experiments yielded quantitatively similar results. 


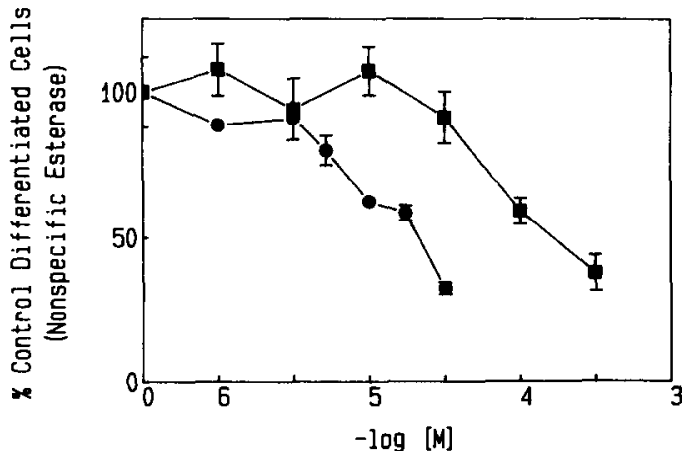

Fig. 2. Concentration-dependent effects of $\mathrm{H}-7$ and HA1004 on calcitriol ( $10 \mathrm{nM})$ induced nonspecific esterase activity, a marker differentiation, in HL-60 cells. Cultures treated with calcitriol for $48 \mathrm{hr}$ were assayed microscopically for cell nonspecific esterase activity and were found to exhibit this marker in $60 \pm 4 \%$ of cells after $48 \mathrm{hr}$. We assayed for cellular nonspecific esterase activity in cultures simultancously treated with calcitriol $(10 \mathrm{nM})$ and various concentrations of $\mathrm{H}-7(\mathbf{)})$ and HA1004 (ם). Data are expressed as percent of control cells exhibiting esterase activity after $10 \mathrm{nM}$ calcitriol treatment $(100 \%)$ in the absence of $\mathrm{H}-7$ or HA 1004 . Each point is the mean of three determinations ( $\pm S E$ ). Four identical experiments yielded quantitatively similar results.

dependent capacities of H-7 and HA1004 to inhibit calcitriol-induced differentiation as measured by total nonspecific esterase activity (NEA). For this marker it was calculated that the $\mathrm{IC}_{50}$ for inhibition of calcitriol-induced differentiation by $\mathrm{H}-7$ was
$20 \mu \mathrm{M}$ and by HA1004 was $165 \mu \mathrm{M}$. Standard error was determined as for the NBT assay. A similar curve for inhibition of those markers of differentiation with $\mathrm{H}-7\left(\mathrm{IC}_{50}=9.0\right)$ was also obtained using $100 \mathrm{nM}$ calcitriol to differentiate cells (data not shown). The $\mathrm{IC}_{50}$ values reported in the abstract were derived by averaging three experiments measuring the effects of H-7 and HA1004 on NBT and nonspecific esterase activity.

Photomicrograph of HL-60 cells. Control cells without kinase inhibitor treated with $10 \mathrm{nM}$ calcitriol or ethanol for $48 \mathrm{hr}$ and assayed for NBT dye reduction capacity are shown in Fig. $3 \mathrm{~A}$ and $\mathrm{B}$. Calcitriol-treated cells that were incubated with $18 \mu \mathrm{M} \mathrm{H}-7$ arc shown in Fig. 3C. A lower percentage of cells were differentiated (dark granulated cells) in calcitriol-treated cells in the presence of $\mathrm{H}-7$ than in cells treated with calcitriol $(10 \mathrm{nM})$ alone. Panels $\mathrm{A}$ C of Fig. 4 are photomicrographs of HL-60 cells stained for nonspecific esterase activity for control cells, calcitriol $(10 \mathrm{nM})$ dosed cells and calcitriol dosed cells in the presence of $18 \mu \mathrm{M} \mathrm{H}-7$ respectively.

Effects of kinase inhibitors on calcitriol-induced inhibition of DNA synthesis. HL-60 cells at $2 \times 10^{5}$ ml were treated with $10 \mathrm{nM}$ calcitriol for $72 \mathrm{hr}$. This time was chosen for assessing DNA synthesis because previous experiments showed that calcitriol did not consistently inhibit DNA synthesis until approximately $72 \mathrm{hr}$. A decrease in DNA synthesis of approximately $50 \%$ was observed (Fig. 5). As shown, $\mathrm{H}-7(18 \mu \mathrm{M})$ was able to reverse the decrease in DNA synthesis. HA1004 also at a concentration of $18 \mu \mathrm{M}$ had no effect on calcitriol-induced inhibition

NBT

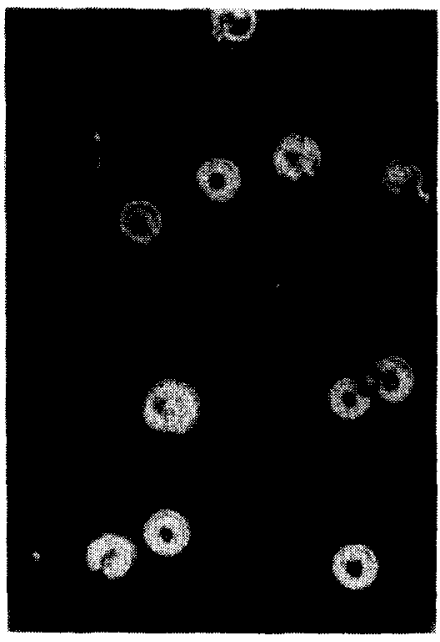

CONTROL

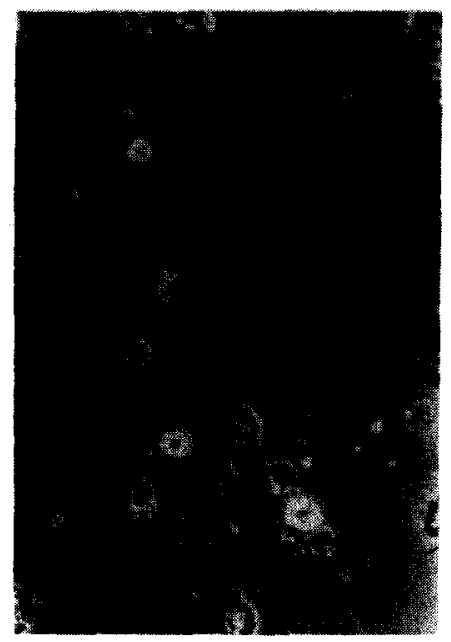

CALCITRIOL $(10 \mathrm{nM})$

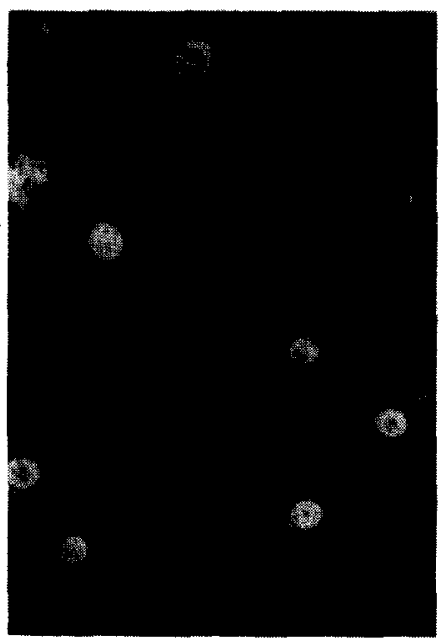

CALCITRIOL (10 nM) H7 (18 UM)

A

B

Fig. 3. Photomicrographs of HL-60 cells $(300 \times)$ assayed for NBT dye reduction. Cells were treated for $48 \mathrm{hr}$ with calcitriol $(10 \mathrm{nM})$ and $\mathrm{H}-7(18 \mu \mathrm{M})$. The cells were then incubated in the presence of $2 \mathrm{mg} /$ $\mathrm{ml} \mathrm{NBT}$ and $500 \mu \mathrm{M}$ TPA for $80 \mathrm{~min}$. and photographed. Key: (A) control cells in the absence of calcitriol and $\mathrm{H}-7$; (B and $\mathrm{C}$ ) calcitriol-treated cells without and with $\mathrm{H}-7$ respectively. 


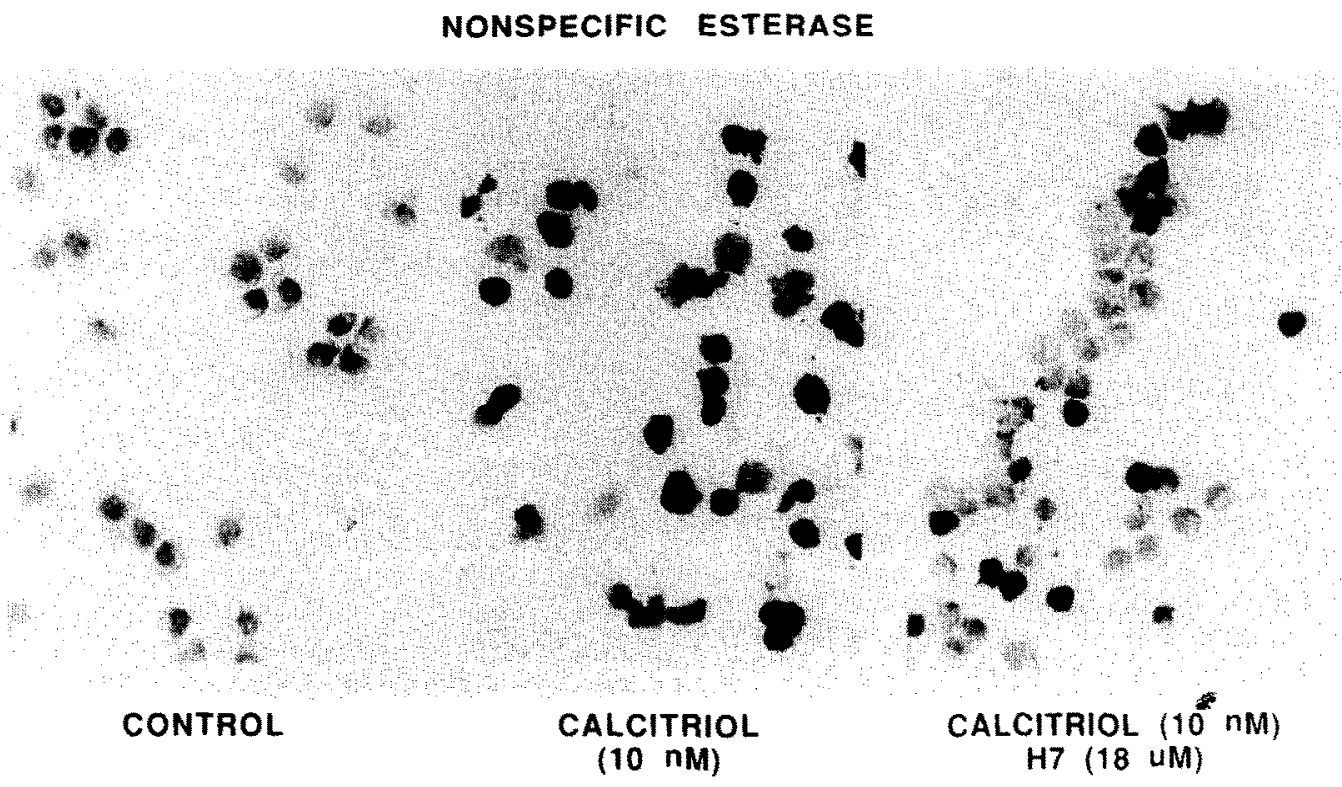

A

B

C

Fig. 4. Photomicrographs $(300 \times)$ of HL-60 cells assayed for nonspecific esterase activity. Cells were treated for $48 \mathrm{hr}$ with calcitriol $(10 \mathrm{nM})$ and $\mathrm{H}-7(18 \mu \mathrm{M})$. Cells were then dried and fixed to a microscope slide followed by a $30-\mathrm{min}$ incubation in the presence of $10 \mathrm{mg} / \mathrm{ml}$ alpha naphthyl acetate and $200 \mu \mathrm{g} /$ $\mathrm{ml}$ Fast Blue RR salt. Counter staining was done with Mayer's hematoxylin solution. Key: (A) photomicrograph of control cells in the absence of calcitriol and H-7; (B and C) calcitriol-treated cells without and with $\mathrm{H}-7$ respectively.

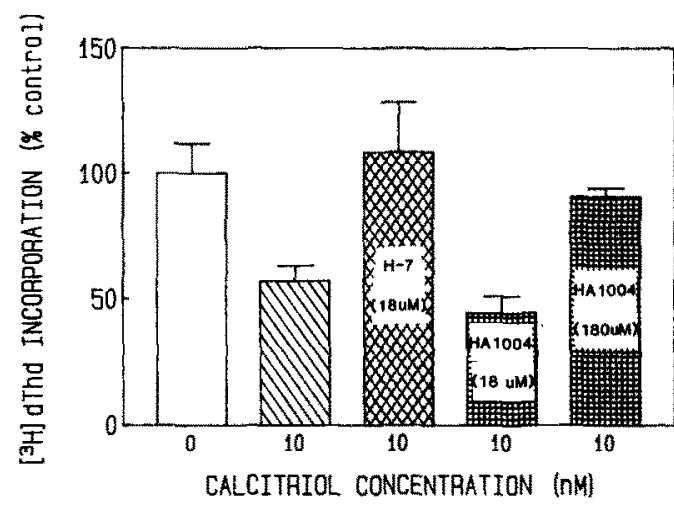

Fig. 5. Effect of calcitriol on DNA synthesis in the absence and presence of $\mathrm{H}-7$ and HA1004 kinase inhibitors. HL-60 cells grown in $10 \%$ horse serum were treated with the indicated concentrations of calcitriol. H-7 and HA1004 for $72 \mathrm{hr}$. Following treatment, cells were assayed for $\left[{ }^{3} \mathrm{H}\right] \mathrm{dTh}$ incorporation as described in Materials and Methods. Results are expressed as percentage of control cells assayed in the absence of calcitriol and kinase inhibitors. Control incorporation was $6587 \mathrm{cpm} / 10^{5}$ cells. Each bar represents the mean $\pm S E$ of four replicates. Mean values for $\left[{ }^{3} \mathrm{H}\right] \mathrm{d} T \mathrm{Thd}$ incorporation in calcitriol-treated cultures and for calcitriol and $\mathrm{HA} 1004(18 u \mathrm{M})$ treated cultures were significantly different from nontreated control cultures as determined by Student's $t$-test $(P<0.01)$. However, mean values reported for calcitriol-treated cells in the presence of H-7 $(18 \mu \mathrm{M})$ and HA1004 $(180 \mu \mathrm{M})$ were not significantly different from control $(P>0.05)$ cultures. of DNA synthesis (Fig. 5). A concentration of $180 \mu \mathrm{M}$ HA1004 was required to block the effect of calcitriol on HL-60 DNA synthesis.

Cell viability. At concentrations greater than $32 \mu \mathrm{M} \mathrm{H}-7$ or $320 \mu \mathrm{M}$ HA1004, cells were unable to exclude trypan blue and were morphologically altered to rough, asymmetric cells. At $32 \mu \mathrm{M} \mathrm{H}-7$ and $320 \mu \mathrm{M}$ HA1004, cells excluded trypan blue and were not differentiated as assessed by NBT dye reduction and NEA (data not shown). However, these concentrations of $\mathrm{H}-7$ and HA1004 yielded morphologically asymmetric cells with many vacuoles. Treatment of cells with concentrations of H-7 from 0 to $18 \mu \mathrm{M}$ or HA1004 from 0 to $100 \mu \mathrm{M}$ had no effect on cell growth, morphology, trypan blue exclusion, and differentiation as determined by our assays. The magnitude of the activity of $\mathrm{H} 7$ and HA1004, as shown in Figs. 1 and 2, was limited by inhibitor toxicity at higher concentrations.

\section{DISCUSSION}

HL-60 promyelocytic leukemia have proven to be useful for studying cellular differentiation. The mechanisms involved in cell differentiation have been examined extensively in this cell line, and correlations of various cellular events with differentiation have yielded insight into the mechanism of cell differentiation [1 9]. HL-60 differentiation occurs in conjunction with, or is preceded by, regu- 
lation of oncogene and enzyme activities, including kinases [21-28]. Our laboratory is interested in the action of calcitriol to differentiate HL-60 cells. In this study, differentiation was assessed by measuring cell NBT dye reduction, nonspecific esterase activity, and cell DNA synthesis. We showed that calcitriol modulates these activities as early as $24 \mathrm{hr}$ after induction $[21,26]$.

Protein phosphorylation plays a significant role in modulating many cellular processes. Kuo, Nishizuka, and collaborators have demonstrated that PKC is an important regulatory enzyme and it is now accepted that the mechanism by which $P K C$ regulates cellular processes, including control of signal transduction, cell division and differentiation, involves specific protein phosphorylation $[29,30]$. The importance of protein kinase $\mathrm{C}$ activity for induction of differentiation in HL-60 cells has been examined. Helfman et al. [31] showed that $\mathrm{Ca}^{2+}$. phospholipid dependent protein kinase $C$ is prevalent in leukemia cell lines including the HL-60 line. Fontana et al. $[27,28]$ demonstrated an elevation in $\mathrm{Ca}^{2+}$-phospholipid dependent protein kinase activity after induction of HL-60 cells with retinoic acid. Kraft and Anderson [32] have also shown this to occur in F9 tetracarcinoma cells.

We previously showed that binding of [3H]phorbol dibutyrate to HL-60 cells increases early in the process of differentiation [15]. This report is our initial attempt to characterize further the importance of PKC activity for HL-60 cell differentiation by making use of the protein kinase inhibitors $\mathrm{H}-7$ and HA1004 which interact directly with the enzyme. Hidaka and others have shown that $\mathrm{H}-7$ produces a selective inhibition of protein kinase $\mathrm{C}$ in platelets, smooth muscle and cardiac muscle without inhibiting other kinases such as myosin light chain kinase [1719], whereas HA1004 is more selective for cAMP, cGMP and myosin light chain kinases. We report here that these inhibitors blocked calcitriol-induced differentiation of HL-60 cells in a dose-dependent manner. Importantly, $\mathrm{H}-7$ was approximately ten times as potent as HA1004 in this regard. Maximal inhibition of differentiation markers was $80 \%$. We show that the total number of cells exhibiting these markers was decreased by treatment with these protein kinase inhibitors (Figs. 1-3). The population of cells that we assume are undifferentiated in all treatment conditions appeared similar to control cells as assayed by NBT reduction and nonspecific esterase activity. Moreover, we have demonstrated that subtoxic doses of protein kinase inhibitors alone did not affect DNA synthesis, cell growth, trypan blue exclusion or cell differentiation markers.

Cell toxicity of kinase inhibitors (H7 and HA1004) was evident at concentrations greater than $32 \mu \mathrm{M}$ for $\mathrm{H}-7$ and greater than $320 \mu \mathrm{M}$ for HA1004. Interestingly, cell toxicity corresponded to approximately five times the reported $K_{i}$ values for inhibition of protein kinase $C$ activity, and toxicity does not correlate with the relative $K_{i}$ values reported for cGMPdependent, cAMP-dependent or myosin light chain (MLC) kinases [17]. Furthermore, the $\mathrm{IC}_{50}$ values obtained from our data of inhibition of differentiation correlated with those values reported for inhibition of PKC phosphorylation in vitro [17].
Although our data are consistent with the hypothesis that protein kinase $\mathrm{C}$ activity is essential for calcitriol induction of differentiation of HL-60 cells, it is correlative. Recently, however, evidence has accumulated to further support this hypothesis. First, calcitriol and phorbol esters (a potent stimulant of kinase $\mathrm{C}$ activity) both induce differentiation of $\mathrm{HL}$ 60 cells along the monocytic pathway [5, 7-9, 21]. Second, Zylber-Katz and Glazer [11] have shown that calcitriol induces an increase in calcium and phospholipid kinase activity concurrent with cell differentiation. Third, calcitriol has been shown to induce an increase in phorbol ester receptors early in the course of differentiation [15]. Fourth, the time course for phorbol ester induced differentiation precedes calcitriol induction $[5,7-9,21]$. Fifth, we show that $\mathrm{H}-7$, a selective inhibitor of PKC activity, blocked calcitriol induction of differentiation. Sixth, HA1004, a kinase inhibitor with a greater relative potency for inhibiting cAMP-dependent cGMPdependent and myosin light chain kinases, was less potent at blocking HL-60 cell differentiation than $\mathrm{H}$ 7. However, it is of interest that the increases in PKC phosphorylation activity and phorbol ester binding capacity are also induced by agents (e.g. DMSO) that differentiate HL-60 cells along the granulocytic pathway $[16,22]$. This suggests that the induction of PKC activity is not sufficient to determine the end product of HL-60 cell differentiation. It further suggests that the determinant for pathway selection, monocyte or granulocyte, may be dictated by activation of distinct PKC isozymes or by factors other than PKC. In summary, data presented here suggest that the action of calcitriol to induce HL-60 cell differentiation requires protein kinase activity and correlates with the concept that protein kinase $\mathrm{C}$ is the responsible kinase.

\section{REFERENCES}

1. Z. Bar-Shavit, S. L. Teitelbaum, P. Reitsma, A. Hall L. E. Pegg, J. Trial and A. J. Kahn, Proc. natn. Acad. Sci. U.S.A. 80, 5707 (1983).

2. T. R. Breitman, S. E. Selonick and S. J. Collins, Proc. nain. Acad. Sci. U.S.A. 77, 2936 (1980).

3. S. J. Collins, F. W. Ruscetti, R. E. Gallagher and R C. Gallo, Proc. natn. Acad. Sci. U.S.A. 75, 2458 (1978)

4. S. J. Collins, F. W. Ruscetti, R. E. Gallagher and R. C. Gallo, J. exp. Med. 149, 969 (1978).

5. E. Huberman and M. F. Callahan, Proc. natn. Acad. Sci. U.S.A. 76, 1293 (1979).

6. J. Lotem and L. Sachs, Proc. natn. Acad. Sci. U.S.A 76, 5158 (1979).

7. D. J. Mangelsdorf, H. P. Koeffler, C. A. Donaldson, J. W. Pike and M. R. Haussler, J. Cell Biol. 98, 391 (1984).

8. S. Murao, A. Gemmell, M. F. Callahan, N. L. Anderson and E. Huberman, Cancer Res. 43, 4989 (1983)

9. G. Rovera, D. Santoli and C. Damsky, Proc. natn. Acad. Sci. U.S.A. 76, 2779 (1979).

10. U. Kikkawa, Y. Takai, Y. Tanaka, R. Miyake and Y. Nishizuka, J. biol. Chem. 258, 11442 (1983).

11. J. E. Niedel, L. J. Kuhn and G. R. Vandenbark, Proc. natn. Acad. Sci. U.S.A. 80, 36 (1983)

12. N. A. Sharkey, K. L. Leach and P. M. Blumberg, Proc. natn. Acad. Sci. U.S.A. 81, 607 (1984).

13. M. Castagna, Y. Takai, K. Kaibuchi, K. Sano, U Kikkawa and Y. Nishizuka, J. biol. Chem. 257, 7847 (1982). 
14. K. Kaibuchi, Y. Takai, M. Sawamura, M. Hoshijima, 24. I. F. Grosso and H. C. Pitot, Cancer Res. 45, 847 T. Fukikura and Y. Nishizuka, J. biol. Chem. 257, 13341 (1982).

15. R. E. Martell, R. U. Simpson and J. M. Taylor, J. biol. Chem. 262, 5570 (1987).

16. R. W. Lane, R. J. Sturm, J. F. Borzelleca and R. A Carchman, Cancer Res. 46, 3782 (1986).

17. H. Hidaka, M. Ingaki, S. Kawamoto and Y. Sasaki, Biochemistry 23, 5036 (1984).

18. S. Kawamoto and H. Hidaka, Biochem. biophys. Res Commun. 125, 258 (1984).

19. T. Asano and H. Hidaka, J. Pharmac. exp. Ther. 231, 141 (1984).

20. M. M. Bradford, Analyt. Biochem. 72, 248 (1976).

21. E. H. Bresnick and R. U. Simpson, Cancer Res. 46, 7879 (1986).

22. E. Zylber-Katz and R. I. Glazer, Cancer Res. 45, 5159 (1985).

23. G. P. Studzinski, A. K. Ghandal and Z. S. Brelvi, Proc. Soc. exp. Biol. Med. 179, 288 (1985). (1985).

25. P. H. Reitzma, P. G. Rothberg, S. M. Astrin, J. Trial, Z. Bar-Shavits, A. Hall, A. Teitelbaum and A. J. Kahn, Nature Lond. 306, 492 (1983).

26. R. U. Simpson, T. Hsu, D. A. Begley, B. S. Mitchell and B. N. Alizadeh, J. biol. Chem. 262, 4104 (1987).

27. J. A. Fontana, A. Reppucci, J. P. Durham and D. Miranda, Cancer Res. 46, 2468 (1986).

28. J. A. Fontana, C. Elmer, K. Ku, J. K. McClung, F. R. Butcher and J. P. Durham, J. cell. Physiol. 120, 49 (1984).

29. J. F. Kuo, R. C. Schatzman, R. S. Turner and G. J Mazzei, Molec. cell. Endocr. 35, 65 (1984).

30. Y. Nishizuka, Nature, Lond. 308, 693 (1984).

31. D. M. Helfman, K. C. Barnes, J. M. Kinkade, W. R. Vogler, M. Shoji and J. F. Kuo, Cancer Res. 43, 2995 (1983).

32. A. S. Kraft and W. B. Anderson, Nature, Lond. 301, 621 (1983). 